\title{
Education and Science
}

Vol 41 (2016) No 184 27-48

\section{Six Reasons to Teach Undergraduate Courses in SCALE-UP Classrooms: Suggestions for Higher Education Authorities and Instructors}

\author{
Mustafa Erol ${ }^{1}$, Ahmet Özcan ${ }^{2}$, Julie Anne Luft ${ }^{3}$
}

\begin{abstract}
In Turkey, funding for higher education institutions has increased drastically in the last ten years. This has caused a profound increase in the number of new universities and undergraduates. As a result, there has been a focus on the design and construction of new buildings on the campuses, but not in the design of the classrooms. This oversight has resulted in omission of contemporary active learning environments such as Student-Centered Active Learning Environment with Upside-down Pedagogies (SCALE-UP).
\end{abstract}

SCALE-UP classrooms are highly interactive learning environments equipped with technologies for large enrollment introductory undergraduate courses. They were initially designed to cultivate student learning through collaborative problem solving in the sciences. In a SCALE-UP classroom, the instructor circulates around the room and asks students questions, encourages students to share their work, and supports student learning in groups. This pedagogical approach encourages students to question and collaborate with their peers, while learning content.

In this paper, the SCALE-UP approach was explored with an experiential qualitative method through observations, interviews, and various documents. The observations occurred in different SCALE-UP classrooms over the course of a semester. Interviews were also completed with the creator of the SCALE-UP classroom, who also coordinates a network all around the world. In addition, the first author's journal regarding SCALE-UP classrooms was a source of information.

Although the SCALE-UP system is catching on globally, it is a new concept for Turkish universities. The increase in student learning and the desire to learn in this novel setting reinforce the importance of this classroom design. With these results, we suggest to the authorities and instructors of the Turkish universities that SCALEUP classrooms should be implemented throughout Turkey.
Keywords

Higher education

SCALE-UP classroom

Active learning

Technology incorporation

Experiential Qualitative Method

Practitioner inquiry

Article Info

Received: 30.12.2015

Accepted: 11.04.2016

Online Published: 27.04.2016

${ }^{1}$ (Corresponding Author) Bozok University, Faculty of Education, Department of Science Education, Turkey,

mustafa.erol@bozok.edu.tr

${ }^{2}$ Bozok University, Department of Foreign Languages, Turkey, ahmet.ozcan@bozok.edu.tr

${ }^{3}$ University of Georgia, College of Education, Department of Science and Mathematics Education, USA, jaluft@uga.edu 


\section{Introduction}

Turkey is unique in its demographics, having the youngest population among the European countries. In response to the need for an educated young population, officials in the Turkish government have increased the funding for universities. The budget for higher education institutions has risen from TRY 5.85 billion (MOF, 2006) to TRY 15.18 billion per year (MOF, 2014) in eight years. The results of this initiative have been profound. At the beginning of 2006, there were 77 universities in Turkey (Günay \& Günay, 2011); however, in just eight years, the number of universities has increased to 184 (Çetinsaya, 2014). Along with the increase in universities, there has been an increase in the student population, which is now at 5.5 million and corresponds to a $125 \%$ increase in students.

Unfortunately, the rapid expansion has triggered some debates about the quality of higher education in Turkey (Özoğlu, Gür, \& Gümüş, 2016). It is possible to say that the priority of the authorities of these new universities is the construction of new buildings and campuses, but the development of the classrooms has not kept up with emerging classroom design principles (e.g. large tables for group work, technology incorporation, computers for students, interactive white-boards). As a result, the learning environments at these universities are mostly traditional lecture-type classrooms. Another issue is that professional development programs have not been funded or prioritized for undergraduate instructors. Keeping up-to-date with emerging undergraduate instructional strategies should be considered in the expansion of the universities. It is not enough to teach more undergraduates; they need to be taught in a way that supports their learning of the different content areas.

A purposeful literature review to understand the current situation of active learning environments in Turkey reveals that most active learning occurs in middle (Akınoğlu \& Tandoğan, 2007; Aydede \& Matyar, 2009; Memnun, 2008) and high schools (Tuna, 2012a). Often prospective teachers (Taçman, 2007) and in-service teachers (Karamustafaoğlu, Coştu, \& Ayas, 2006; Tuna, 2012b) are the subjects who are enacting active learning. Unfortunately, the studies about active learning environments are for short research periods and not for an entire semester or for a year. Clearly missing from these Turkish studies is a focus on active learning in higher education (Kalem \& Fer, 2003; Taçman, 2007). The importance of the active learning approach should not be disregarded at the undergraduate level.

In the US, for instance, there is broad support for active learning. Recently, this support was highlighted through a metaanalysis of 225 studies comparing traditional and active learning in science, technology, engineering and mathematics (STEM) classes. Examination scores and failure rates of students in traditional and active learning STEM courses at the undergraduate level were compared and the results showed that active learning approaches increased the students' performance (Freeman et al., 2014). This data is compelling and it is important to disseminate information about the active learning approach in Turkey.

In the active learning method, in contrast to traditional learning methods, the instructor facilitates the learning of the students. For an instructor who is used to teaching in a classical didactic lecturing style, it will be important to have resources and professional development pertaining to active learning. Erol, Idsardi, Luft, Myers, and Lemons (2015) have suggested a potential learning progression related to active learning, but instructors will need professional development. One of the first issues essential in the use of active learning is to learn more about the active learning.

This paper reports on the experiences of a science instructor who studied an active learning approach in the sciences, and shares important information about enacting this approach at the undergraduate level. It specifically investigates the use of an active learning environment referred to as Student-Centered Active Learning Environment with Upside-down Pedagogies (SCALE-UP). The SCALE-UP approach is one of the leading contemporary active learning environments. There are 250+ SCALE-UP sites across the US that accommodates different numbers of students (30-300). This approach is expanding globally (SCALE-UP, 2015), and would be useful for instructors at Turkish 
universities. In order to provide information about the SCALE-UP approach, this paper reports on a purposeful examination of SCALE-UP classroom use in one region in the US. Specifically, the aim of this paper is to:

1) Discuss active learning and SCALE-UP classrooms,

2) Report on the observed and experienced use of the SCALE-UP classroom,

3) Suggest how Turkish authorities could support SCALE-UP implementation.

Analytical discussions about potential educational innovations are important in education. This paper uses a practitioner inquiry framework in order to understand one instructor's experience with the SCALE-UP approach. Even though the data and information came from outside of Turkey, the researcher practitioner (a physics instructor) was Turkish and considered the innovation in light of Turkey's current educational position. Not interviewing with the students may be stated as a limitation of this study. This type of inquiry does not involve a research clearance, but it analyzes a current educational setting to make important contributions to instructors and policymakers in Turkey.

\section{Relevant Literature}

\section{Active Learning Environments for Undergraduate Courses}

The American Association of Higher Education has highlighted seven principles of good practice for educating undergraduates, including (1) encouraging student-faculty contact, (2) encouraging cooperation, (3) encouraging active learning, (4) giving prompt feedback, (5) emphasizing time on task, (6) communicating high expectations and (7) respecting diverse talents and ways of learning (Chickering \& Gamson, 1987). Many studies in undergraduate education, along with new developments and adaptations in classroom instruction utilize these principles (Bangert, 2004; Chickering \& Gamson, 1991; Chickering \& Gamson, 1999; Crews, Wilkinson, \& Neill 2015; Leibold \& Schwarz, 2015; Mandell, 2016; McCabe \& Meuter, 2011; Panther Bishoff, 2010; Tirrell \& Quick, 2012).

Drawing upon these principles, researchers and instructors are exploring new ways to teach undergraduate courses. Some of these attempts have resulted in the following approaches, which also embrace active learning: workshop classrooms (Laws, 1991, 2004), studio classrooms (Cummings, Marx, Thornton, \& Kuhl, 1999; Sorensen, Churukian, Maleki, \& Zollman, 2006; Hoellwarth, Moelter, \& Knight, 2005), peer instruction (Mazur, 1997; Crouch \& Mazur, 2001), open laboratory (Mintzes, 2006), hybrid lecture/studio (Furtak \& Ohno, 2001; Kohl \& Kuo, 2012), Technology Enabled Active Learning (TEAL) (Dori \& Belcher, 2005; Beichner, Dori, \& Belcher, 2006), interactive lecture demonstrations (Sokoloff \& Thorton, 1997), and Transform, Interact, Learn, Engage (TILE) (Van Horne, Murniati, Gaffney, \& Jesse, 2012; Florman, 2014). All these innovative approaches have been found to result in increased student learning and to offer advantages in terms of integrating technology into the learning environment.

One of the increasingly popular approaches is the use of the SCALE-UP classroom. SCALEUP classrooms have the additional benefits of collaboration with peers, active engagement, interaction with faculty, and use of technology to represent and support student learning. Furthermore, with the decreasing attention spans of students in classrooms (Barnes, Marateo, \& Ferris, 2007; McLaughlin et al., 2014), SCALE-UP classrooms create an engaging atmosphere. This is done by creating an active learning environment that prefers teaching by questions instead of providing information (Mazur, 2009). It also engages students in purposeful activities and provides students with opportunities to reflect on their emerging knowledge, which supports their learning. Active learning increases students' conceptual understanding, while capturing their attention, and develops enhanced critical thinking skills (Prince, 2004).

In SCALE-UP classrooms, the learning spaces are redesigned to engage students in active learning environment. In this type of classrooms, class time is spent collaborating on carefully planned inquiry-based activities. This shifts the learning environment from a teacher-centered to a student- 
centered classroom. As a result, students achieve better scores in problem solving and on conceptual exams (Gaffney, Richards, Kustusch, Ding, \& Beichner, 2008), improve their attitudes about science and have less attrition from historically difficult courses (Beichner \& Saul, 2003; Beichner et al., 2007; Singer, Nielsen, \& Schweingruber, 2012).

\section{SCALE-UP Classrooms}

A SCALE-UP classroom is a comfortable classroom environment that includes technology in order to promote active and collaborative learning. Originally focused on crowded college classrooms, 'SCALE-UP' stood for Student-Centered Activities for Large Enrollment Undergraduate Physics. After its incorporation in different disciplines and with different sizes of enrollment, 'SCALE-UP' was changed to stand for Student-Centered Active Learning Environment for Undergraduate Programs. Then, as high school instructors saw value in this approach, 'SCALE-UP' was converted to Student-Centered Active Learning Environment with Upside-down Pedagogies.

The main pedagogy of the SCALE-UP approach consists of encouraging students to collaborate with their peers, questioning and teaching one another; minimizing lectures during class and assisting students in answering their own questions (Beichner et al., 2007).

A SCALE-UP classroom is like a restaurant in which students sit in three groups of three students at 7 foot (2.13 meter) round tables with nametags. The instructor's small table is placed in the center of the room. Each student has his/her own laptop, or each group has a desktop computer. The instructor uses a video presentation system, document camera, projectors, etc., which is incorporated into the lessons. All groups have small whiteboards for their collaborative work, problem solving or presentations. Each table has a big public discussion whiteboard, as well. In this classroom, students work in groups, and the instructor circulates around the tables to engage students. A possible SCALEUP layout can hold 99 students in a 40' × 50' room. (Gaffney et al., 2008).

\section{Summary}

In the opening paragraphs of this paper, it was noted that there has been a rapid expansion of higher education institutions during the last decade in Turkey. This has impacted Turkish institutions of higher education in numerous ways, but primarily in the increase of students per instructor. In these large class settings, the quality of instruction has reduced (Özoğlu et al., 2016). One way in which to support instructors may be through the use of active learning. Active learning has been shown to improve learning at the undergraduate level. There are several approaches in creating an active learning environment, with SCALE-UP instruction being used internationally. In fact, SCALEUP classrooms have great promise for Turkish universities. This paper explores the use and SCALEUP classrooms and suggests how they can support student learning in the crowded classrooms in Turkey. 


\section{Methodological Approach}

\section{An Inquiry by a Practitioner}

There are many approaches to the study of classrooms. In this study, we employed an experiential qualitative approach that inquires into teaching in a SCALE-UP setting with the goal of making the instruction public, open to critique and accessible by those in the professional community (Cochran-Smith \& Donnell, 2006). This approach closely aligns with practitioner inquiry, which includes the collection of information and data with the goal of analyzing this information and creating scholarship in the area of teaching and learning (Cochran-Smith \& Donnell, 2006). This approach is appropriate because the SCALE-UP classroom is a new concept for Turkish universities and it is not well-known or implemented in Turkey. By having a Turkish instructor explore the teaching and learning in a SCALE-UP community in the US, it is possible to reveal the potential and limitations of the SCALE-UP classroom in Turkey. Ultimately, the perspective of the Turkish instructor translates the US experience to the classrooms of Turkey. This instructional innovation is shared with the goal of making his experience public and open to discussion.

\section{Participants}

The data for this inquiry were obtained by observation, interviews, and the first author's journal. There was an initial focus on physics instruction. The observed study group includes a class of first-year undergraduate engineering students who were enrolled in a physics course for engineers in the fall of 2014. The course occurred in a large public institution in the US. This was the only group in the SCALE-UP classroom that was available to observe. The course is three hours in a week, on Monday, Wednesday and Friday, one hour for each day. Laboratory activities are carried out on Wednesdays. Attendance to the class is required and most of the $70+$ students attended the course during the observation.

In order to enhance the knowledge of the researcher practitioner, interviews were conducted with different individuals. One person was the designer of the SCALE-UP classroom, Robert Beichner, a Physics Professor at North Carolina State University. Dr. Beichner studies SCALE-UP approach and coordinates a network which consists of more than 250 SCALE-UP classrooms across the US and many classrooms around the world. Additional interviews were conducted with instructors of different SCALE-UP classrooms, who were also experienced in teaching with this system.

An important participant in this study was the first author, who kept a journal about his experiences with the SCALE-UP classroom. He was a visiting physics professor at a large public institution in the US in 2014-2015. He wanted to improve his knowledge of teaching at the undergraduate level, and specifically studied contemporary active learning environments. With experience in teaching science and integrating technology into his instruction in Turkey, he was enthusiastic to expand his knowledge of educational innovations.

\section{Data Collection}

Before the observations, interviews, or journal writing, the literature on SCALE-UP classrooms was reviewed and main themes were determined in accordance with the aim of the study. Then, two instructors, who are experienced in SCALE-UP, and one faculty member, who was experienced in practitioner inquiries, discussed these themes. After this step, SCALE-UP classroom were observed in terms of physical environment, teaching and learning processes, and disadvantages. Interviews were also conducted, and a journal was kept.

Observations were made in 2014, Fall Semester by one of the researchers. All of the SCALEUP instruction at one institution was observed and it took over 14 weeks. In the first week of observations, the instructor of the course introduced the practitioner to the class and informed them about his inquiry into SCALE-UP classrooms and his observation of the class. During the observations, the practitioner took extensive notes about the pre-determined themes (e.g. physical environment, disadvantages) during the course. SCALE-UP instruction was also observed at another institution, but this consisted of just a few days. 
When interviews were conduced, they were created to collect information about the physical environment, teaching and learning process, and disadvantages in using this type of instruction. The questions were reviewed by a person knowledgeable of interviewing and practitioner inquiries.

One set of interviews occurred with the instructor of the course. These interviews occurred after the observations, and focused on the observed instruction. The instructor often provided additional insights into the observations.

An important interview occurred with Dr. Beichner and it took four hours over two days. Some part of the interview was made in the class (during the course) and another part was done in his office. During the interview, observation notes were shared with Dr. Beichner and his opinions were noted. While a tape recorder was not used; his answers were recorded by taking notes during the interview.

A SCALE-UP journal was written by the researcher practitioner for each observed week. The researcher practitioner wrote his opinions and feelings about positive and negative points of the SCALE-UP class in this journal. This journal was analyzed by the second researcher with a purpose of having a deeper sense about SCALE-UP phenomenon and in order to contribute to this inquiry.

\section{Validity and Reliability}

Even though this is a practitioner inquiry, there was attention given to validity and reliability. Specifically, validity and reliability were carried out in accordance with suggestions in the literature (Merriam, 2013; Miles \& Huberman, 1994; Patton, 2014; Yıldırım \& Şimşek, 2011), and are explained below:

1. In this study, various data collection methods such as observation, interview and document analysis were implemented for internal validity and external reliability.

2. In order to increase internal validity, related literature has been reviewed and a conceptual framework was determined about the subject. Expert opinions were taken for observation issues and interview questions, and recommended changes were made. Observation and interview notes were shared with the related people and received confirmation from the participants.

3. Research process and procedures are reported in a detailed manner in order to ensure external validity. In this context; research model, study group, data collection process, and data analysis are explained in detail.

4. Observation and interview notes were coded by two researchers individually, and consistency value was calculated. Besides, a SCALE-UP journal was coded by the second researcher and those codes were examined by the researcher practitioner and confirmed by him. For instance, the "preparation" and "financial problems" codes in "challenges" theme is obtained from the journal by second researcher. These problems have not been observed during the course, yet they have been noted as possible challenges while writing the journal after the course. The researcher practitioner agreed with these codes.

5. The findings have been supported with direct quotes from the interviews and journal in order to ensure reliability.

\section{Data Analysis}

Descriptive analysis was performed in order to analyze the data. In descriptive analysis, data are summarized and interpreted according to predetermined themes (Yıldırım \& Şimsek, 2011, p. 224). The data were coded by two researchers, and then assigned to the generated themes and sub-themes. NVivo, a qualitative software coding program, was also used in the data analysis process. The reliability of the coding of the two researchers have been calculated by using Miles and Huberman's (1994) interrater reliability formula (reliability = number of agreements) / (total number of agreements + disagreements) and the interrater reliability has been determined to be $94 \%$. The codes that were not consistent between the researchers were in "classroom environment" and "teaching" themes. For example, teaching assistant and learning assistant were coded under "environment" themes by one of the researchers, but the other researcher coded it under "teaching". 


\section{Results}

In this examination of the SCALE-UP classroom, there was an analysis of observations, interviews, and the practitioner's journal. The analysis consisted of codes, which resulted in different findings and models. The models and findings will be discussed in this section, and will consist of a discussion of the SCALE-UP environment, learning in the SCALE-UP classrooms, teaching in the SCALE-UP classroom, and challenges in working in the SCALE-UP classroom. It should be noted that the models are representations of the relationships of the different codes. The linkages and grouping of the codes were evident as the codes and data sources were reviewed multiple times. The associated discussion reveals the different linkages of the model.

\section{SCALE-UP Environment}

The SCALE-UP environment, per the analysis of observations, interviews and the journal, is depicted in Figure 1. Environment in this model is composed of the components used to teach class, the tools (non-technological) in the classroom, and the medium that students experienced.

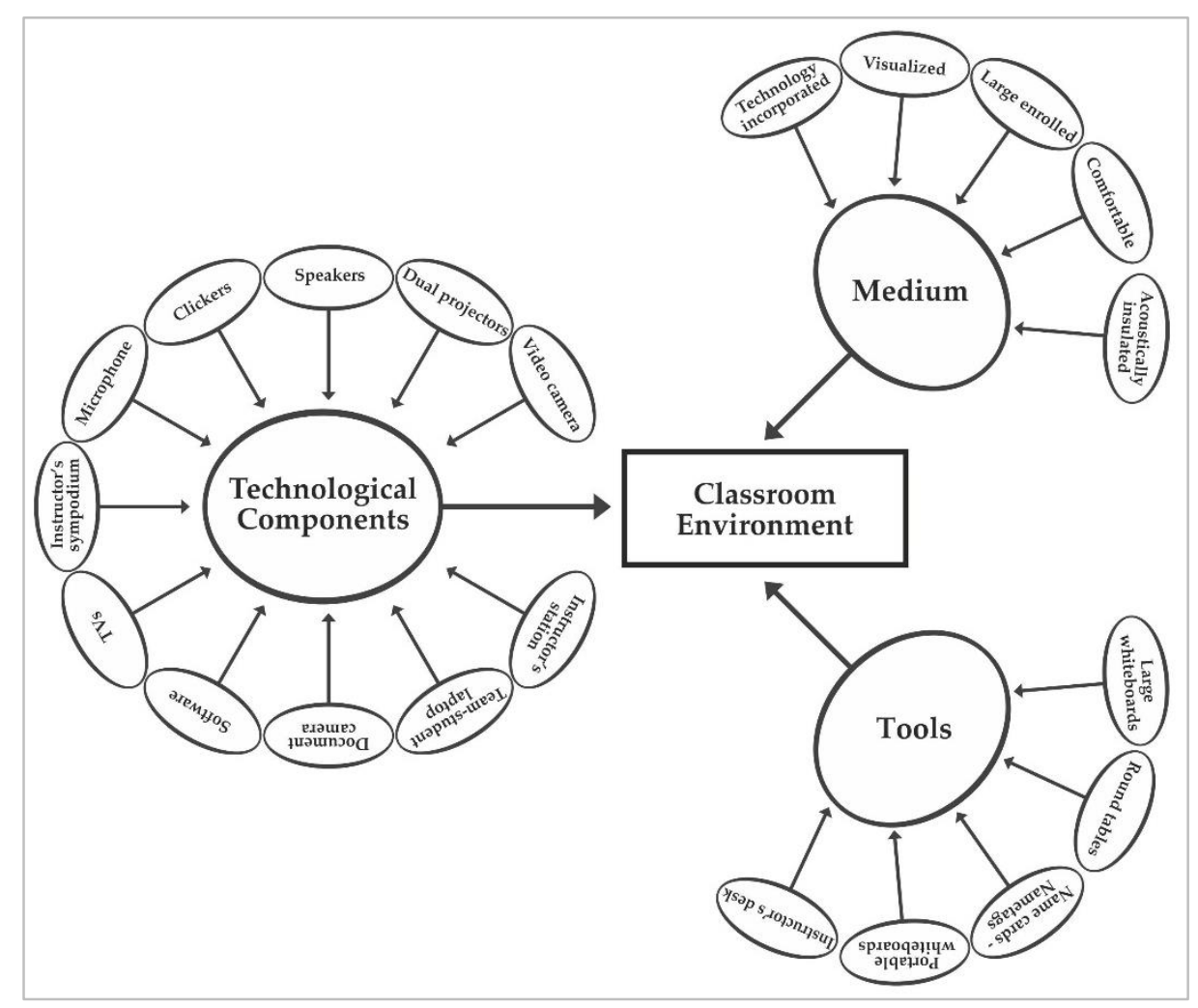

Figure 1. SCALE-UP Environment

In examining the model, it is clear that SCALE-UP classrooms have various technological devices which do not exist in traditional classes. Moreover, the tables and chairs of the students are comfortable, the acoustics of the class are good and the students have good visuals. The practitioner was surprised by the environment:

When I first entered the class, I felt as if I was not in a class, but in a workshop saloon. Design of the classroom, tables and chairs were really different from the classrooms that I thought. Acoustic insulation was also good, there was not humming in the class and the instructor could be heard easily by everyone. 
Also the classes have numerous students; therefore the numbers of students are much more than a typical class. Beichner states that:

Even if they seem like high cost classes, SCALE-UP classes are more economic than traditional classes because they are large-enrolled and an instructor and a teaching assistant are enough for 99 students.

The practitioner states that:

Initially, I thought such a crowded group of students could make the classroom management so difficult and I did not believe it would be an effective lecture. But day after day, I observed a really good learning opportunity.

As stated above, there are many technological components in SCALE-UP classrooms. One of the most remarkable of the technological devices is the instructor's station. On this unit, the instructor manages all the devices such as team laptops, sympodium, video camera, document camera, clickers, software, dual projectors, TVs, microphone and speakers. There are laptops for each student or a desktop computer for each group in the class. The students use them during the course for various purposes such as doing research, preparing reports or presentations. The teacher writes on the sympodium and all the students see that on the screen. Also, the teacher can show a document or a book figure by using the document camera and students can follow an experiment or a demonstration, thanks to the video camera. There is a microphone and some speakers in the class and students can easily hear the teacher. All these devices are connected to the instructor's station. The instructor of the class states that:

This system was designed in order to increase instructor and student motivation and to avoid waste of time. Controlling all the components on the station provides great convenience during the course.

The following statements are notes of the practitioner in the journal:

The desk of the instructor was in the middle of the class and unlike a traditional instructor's desk was full of books and notes on it; it seemed like a control center. Controlling all the technological components on this desk with buttons was interesting.

Using document camera and video camera in a lecture is really interesting and practical. They are connected to instructor's station and students can see a document or follow an experiment on their chairs.

There are also clickers for each student in the SCALE-UP classroom. These devices provide a more interactive learning environment in the classroom. Beichner states:

Data collection is easier with clickers and misconceptions of the students may be identified more easily and quickly, thanks to them. So it saves time.

In addition to technological devices and round tables, there are some tools in SCALE-UP classrooms such as portable whiteboards, large whiteboards and name cards/nametags. On each table, there are nine students and three of them form a group. Each table has portable whiteboards to present their work. There are also large whiteboards in the classroom and all the students can easily see them. About these tools, Dr. Beichner states:

Initially, the tables were not round; they were rectangle or square for different numbers of students. After many phases, we decided that the most ideal one was the round table for nine students. ... Portable whiteboards are effective tools for group work and discussion. And large whiteboards enable students to be relaxed in the class. 
A unique part of the SCALE-UP classroom is the personal feel of the class. This is done with the use of nametags, which allowed students to know each other. The values of names were noted in the journal:

I think nametags motivate the students and make them attached to the class and course....

This was evident as students talked to one another about their solutions. An entry from the journal illustrates that students were interested in talking to one another:

One week before the mid-term exam Dr. Beichner gave a problem to each group and wanted them to solve it. Then, all the students discussed the solutions in their own group, and solved on their own large whiteboards.

In short, it can be said that the SCALE-UP classroom includes various technologies that can support student learning. With these various technological tools, students have different ways to construct their knowledge and to interact with each other and the teacher. These technologies are not always in a traditional classroom.

\section{Learning in SCALE-UP Classroom}

In the learning theme, there were four areas: approaches, climate, activities and benefits. The model generated from the findings is presented in Figure 2.

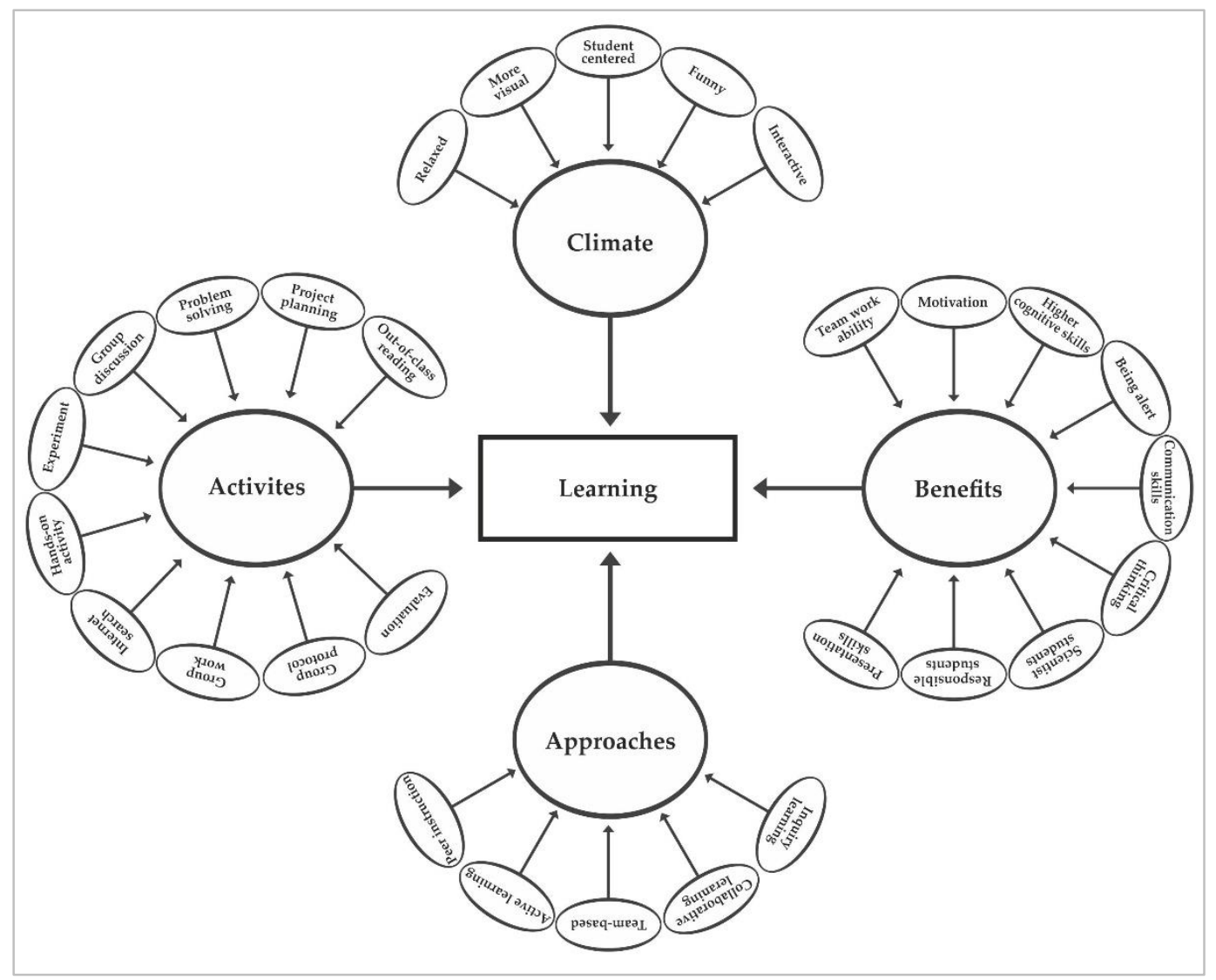

Figure 2. Learning Medium of a SCALE-UP Classroom 
Various learning approaches were used in SCALE-UP classroom. First of all, learning is highly active. All the students joined in the learning process and they were always engaged in different activities. They did experiments or presentations, answered the clicker questions or searched for information on the internet. The practitioner is amazed by the environment:

I think SCALE-UP classroom is a good example for active learning. The students are always doing something and they are experimenting, asking each other and researching together. Sometimes they do experiments or they prepare a presentation, they discuss something or they do research on the Internet.

The students also learn collaboratively, because the SCALE-UP is a team-based classroom. There are various teams; each consists of members who are not randomly assigned to the team. In order to promote peer instruction, members of the teams are chosen purposefully. Dr. Beichner says:

I group the students in the classroom through a criterion, such as previous physics grades, GPAs or high school graduation grades. I categorise the list of the students as high, medium and low, and then, by choosing one from each level to form a heterogeneous group having three members and homogeneous classroom. In this way, the students help each other during the lesson. I also add 5 group bonus points if the grades of their peers increase.

The climate in a SCALE-UP classroom was observed to be easy and relaxed-students were enjoying the activities. The class is also more visual; there were projector screens, laptops and whiteboards in the class. Moreover, the class was student-centered. The lecturing was minimized; students worked together, questioned each other, developed ideas, and presented their findings. Not surprisingly, student-student and student-instructor interaction was high during the lessons. This was a direct result of the grouping of students, and the new role of the instructor, which allowed him to visit each group and discuss their ideas. The practitioner reports that:

The class is much more visual than traditional classes. There are visual elements such as laptops, whiteboards, cameras, and screens in the class. ... the students are very relaxed and the course is funny for them. They are always busy with activities and they enjoy them. The teacher did not lecture very much. He asked a question and then, the course went on with students' answers and activities. I think group competitions can easily be made in these classes and they will be very enjoyable.

There are different kinds of activities such as problem solving, hands-on activities, experiments, group discussion and group work in a SCALE-UP classroom. There are also some activities that are not carried out in the class such as out-of-class readings and assignments. The instructor sometimes gives a problem and wants students to solve them. Then the students do research on the internet, discuss their data in the group and present their findings. The students also do hands-on activities or experiments in the class. They sometimes make projects and evaluate their own work. The most interesting thing is that a group contract is signed at the beginning of the term that requires that they take responsibility for their learning. The journal discusses the activities:

There are a lot to do. The menu is rich, so preparation for the class both for the teachers and students is very important. The activities should be made like a pill to make them active. Because the students do not just sit or listen -- they talk and interact, this class prepares them for life. Because instructors choose specific problems from daily life, students learn team work; decision making, etc... The group contract was really interesting. I think it makes the students more responsible. 
There are many benefits of SCALE-UP classrooms for students. For instance, the students are not passive in these classes and they do not only listen or write something. Their higher cognitive skills such as analysis, evaluation and critical thinking are developed. The group work and presentations contribute to the development of their communication skills, team work abilities and presentation skills. The instructional approaches and climate motivates students, and the group contract makes students more responsible. The students actively engage in the learning process and they study like scientists: they search, try, do experiments and present their work. Because the instructor can reach every student's laptop through his station or he can ask a clicker question, the students are always busy with some activities. They are alert and engaged during the lesson.

This learning environment is clearly captured in the following journal entry:

The students are active in all the lessons. They are searching, asking questions to each other or to instructor, discussing their work and presenting it. They are like a scientist. I think their decision-making and implementation skills develop. Students' participation drew my attention also when I watched the short videos that were prepared by some universities using the SCALE-UP system.

This environment exists because Dr. Beichner envisioned a relaxed learning setting. He wanted a place in which students would talk about their ideas, and this came from the design of a restaurant. He states:

The SCALE-UP classroom came from the idea of restaurant. In this relaxed medium the students and the instructor can easily interact with each other.

In SCALE-UP classrooms, different approaches are used and various activities are performed as shown in Figure 2. The class is student-centered, students enjoy the class and the it has many learning benefits for them.

\section{Teaching in SCALE-UP Classroom}

The findings of the teaching theme are presented under three areas: Practice, process, and resource. The model generated from the findings is presented in Figure 3.

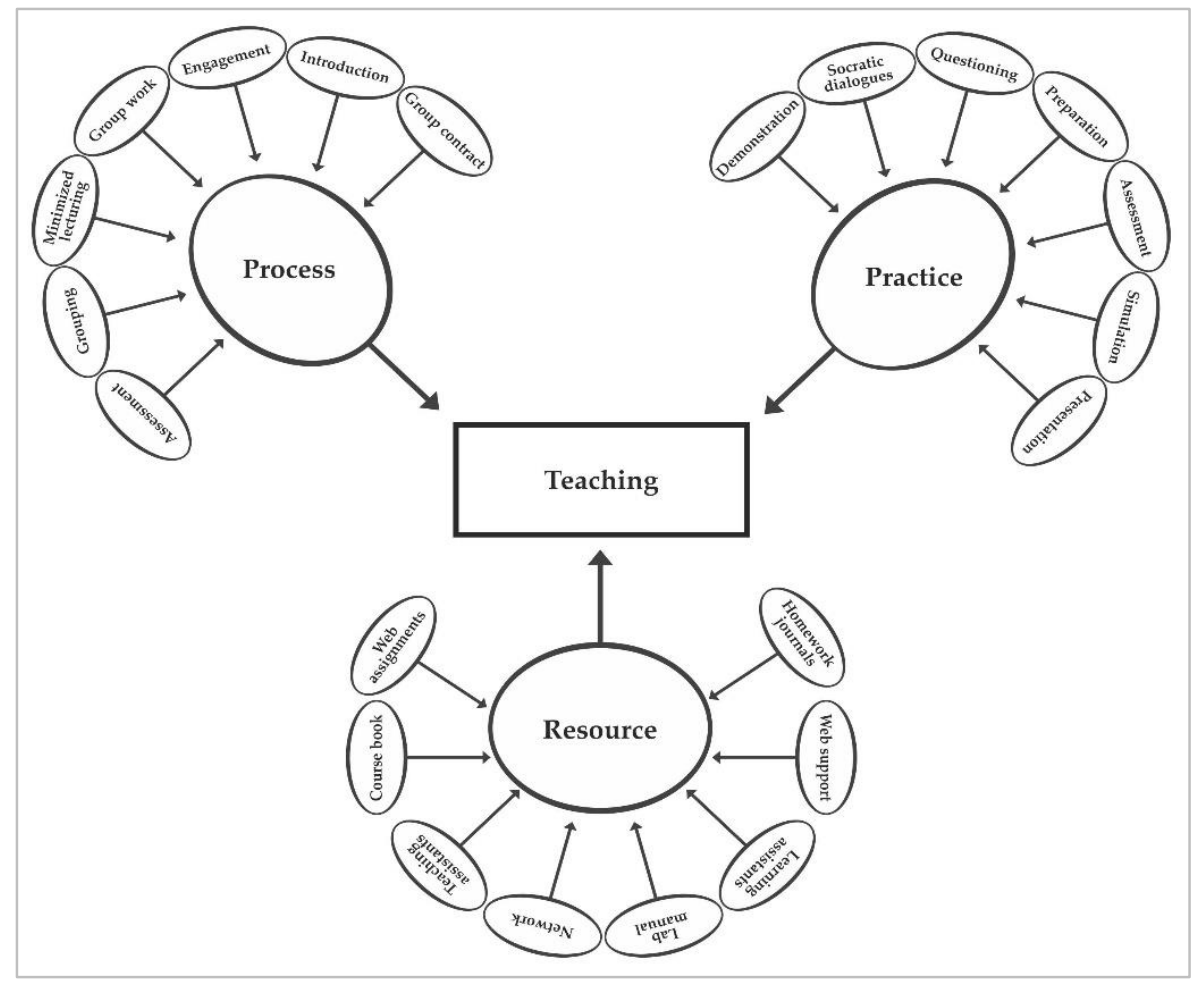

Figure 3. Teaching in the SCALE-UP Classroom 
In this theme, it is clear that the instructor uses different approaches during the lessons. For instance, the instructor uses presentations, demonstrations and simulations by using technological tools in the class. Even though there are a lot of students in the class, every student can easily follow these practices on their laptops or computer screens. The instructor engages the students by using Socratic dialogues. The instructor can also collect data and assess student learning by using clickers. The SCALE-UP classrooms enable instructors to make real time assessments and identify the student's misconceptions easily. The practitioner stated in the journal that:

There are different kinds of instruments to reach the students in this class. The instructor uses a video camera on his station to make experiments and uses a document camera to share information on a paper or a book. He also uses projectors to make presentations and his explanations on the sympodium. Finally, he uses clickers to determine misconceptions periodically.

The instructor of the class states:

Finding and correcting the misconceptions of the students is really easy and I do it very fast by using clickers. Clickers are also real time assessment tools and thanks to them, I can give immediate feedback. The process of teaching begins with grouping the students.

As stated before, the instructor groups the students according to a specific criterion (for example high school grades, GPAs or grades in the previous term, or using a formula which combines them). Then the group members sign a contract at the beginning of the semester and take responsibility. This contract is comprised of some terms and conditions to successfully complete the course and attain the maximum of grade. It also supports the student in terms of understanding all of the content connected to the course curriculum. The articles of the contract contain: attendance, completion of tasks, use of time and resources, and sharing the responsibilies. Therefore, there is quite a bit of group work/discussion in the class.

Even though there is no typical lecturing, the instructor should be more prepared for the course. He or she should plan the activities, questions and tasks in advance so that s/he can instruct properly and engage all the students. There is minimized lecturing in the class. The instructor generally introduces the subject with a question or problem, and then the students start to be active. They answer the questions, do research, make group discussions and prepare presentations. While it might be simple to enact, it is clear that the instructor has to be well-planned to carry this out. This became evident to the observer over time and is noted in the following journal entry:

On the first days of the observation, I had thought that teaching in SCALE-UP is really easy, the instructor did not do much work and the students did something and learned themselves. However, I understood day by day that the instructor does plenty of work before the class. He prepares every moment of the course in order to make students active and direct them for learning. He does not instruct much, but guides the course tactfully. Now, I came to the point that it is harder to teach in this classroom, and being a SCALE-UP class instructor needs more understanding about classroom management, questioning, technology use, etc..

Dr. Beichner says:

Although some instructors think that 10-15 minutes lecturing in SCALE-UP classrooms will be useful, I do not agree with them. I think an inquiry learning experience with no lecturing is more useful.

Teaching assistants (TA) and learning assistants (LA) (third or fourth year students) were also assigned to help the learners in the SCALE-UP classroom. LA assignment is not special to SCALE-UP classrooms, but it was a policy of the university that had the observed SCALE-UP classroom. The TAs and LAs were important in helping students understand the assigned course books and lab manuals. 


\section{Dr. Beichner says:}

Our SCALE-UP project is evolved to large enrolled classrooms and a teaching assistant per 99 students is enough. Actually there is no need for any learning assistants, but it is our university policy to assign them all classes.

The homework associated with the SCALE-UP classroom was also unique. Generally homework was assigned through a web portal. Students prepared their homework and put it in journals or saved it online. Often the homework connected to the instruction of the class. By doing it at home, students were prepared for the class and could be actively engaged.

In terms of instruction, there was a network in which SCALE-UP instructors could meet, share their experiences and find solutions for the new problems encountered in the classes. This network has evolved over many years, and was useful for many of the instructors. Often the instructors contacted each other to acquire curriculum or to understand how to better use their TAs or LAs.

Teaching in a SCALE-UP classroom requires instructional activities to be student-centered. In making a shift to be student-centered, instructors learn how to get students to collaborate. When students collaborate with one another, they learn as a team. Instructors also have to learn how to use different resources to support student learning. Sometimes this involves using technology, while other times it involves using TAs or LAs. Ultimately, teaching in a SCALE-UP classroom requires that instructors pose questions to students, encourage students to work together and present their ideas, and that they interact with students regularly in order to understand the learning of students. This is a significant change from traditional instruction at the university.

\section{Challenges in SCALE-UP Classrooms}

In SCALE-UP classrooms, despite the above-mentioned features, there are challenges for both instructors and students, and there are some physical problems. The model that pertains to the challenges in SCALE-UP classrooms is presented in Figure 4.

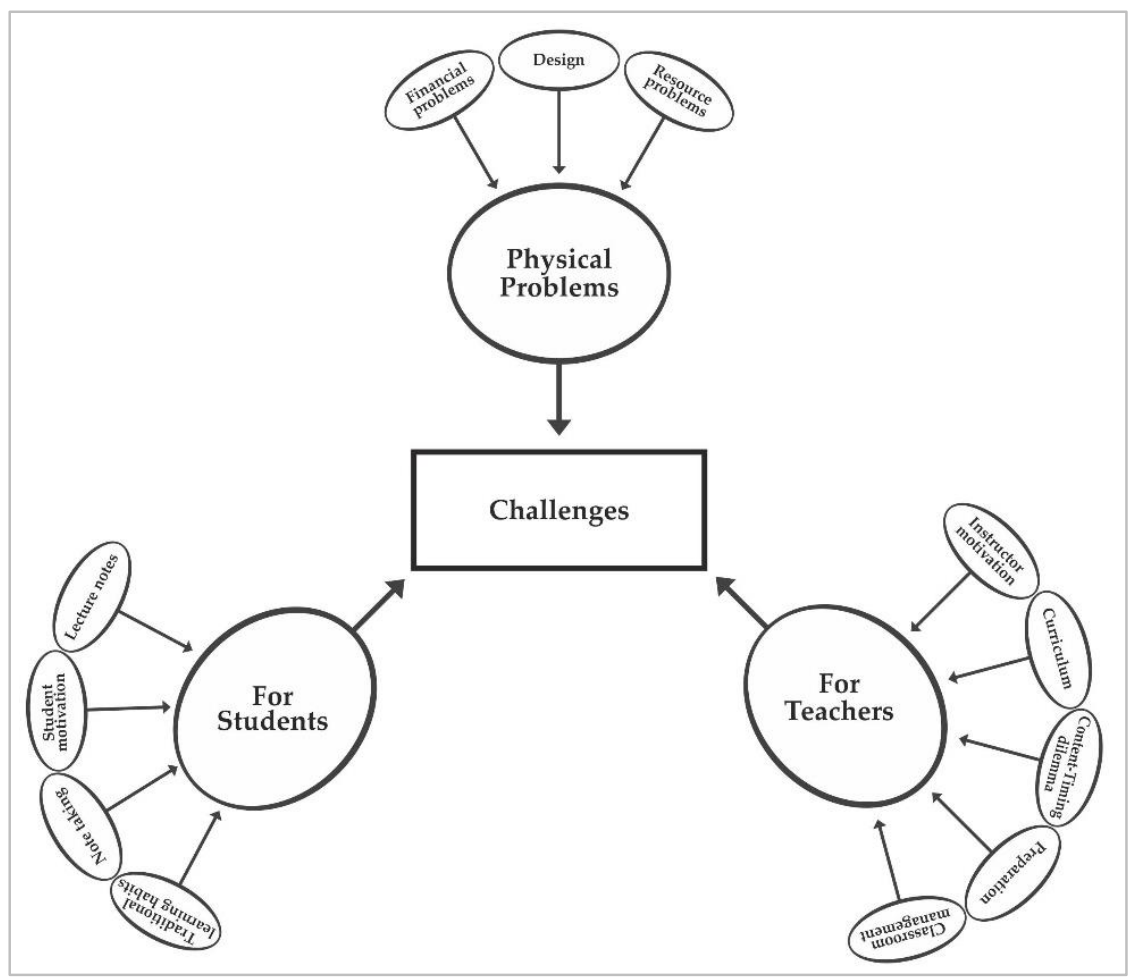

Figure 4. Challenges in SCALE-UP system 
A SCALE-UP classroom is designed for a large number of students. As a result, it needs to be a spacious area with no columns at the middle of the room, and it also needs many technological tools. There must be a large number of special tables and each must have comfortable chairs. The room should be carefully designed. During the observations of the SCALE-UP rooms, it was sometimes observed that the instructor did not use the microphone, which caused that directions for the entire class were not always heard by all students.

Financing the construction and sustainability of these classrooms may be an issue. However, Dr. Beichner says that this is much more economical than other classrooms because "one instructor and one classroom is enough for nearly a hundred students". Administrators may find it expensive at the beginning to establish a SCALE-UP classroom, but the number of students that can be taught by one instructor is significant.

SCALE-UP classrooms need qualified instructors, TAs, LAs who can follow contemporary teaching-learning pedagogies. In addition, technical staffs are needed for the hardware and software, so that they can operate properly.

The practitioner thinks:

The classroom is really big and it should be so because there are many students enrolled hereover 70. It should be designed well because some students may sit far from the teacher. Instructor's station may be in the middle of the class and students' tables should be around it. Depending on the space of SCALE-UP classroom, all tables may be placed as a circle around the instructor's station so that s/he can circulate in the class easily. I think, for this reason, square classrooms will be better than the rectangle ones.

... I doubt if the administrators of universities in Turkey will support these classes financially. First, they may be doubtful about the advantages of it and may find it really expensive to establish a class like the one I observe.

There are some challenges for teachers in SCALE-UP classrooms. Firstly, the instructor should give up his/her old habits - and this may be really difficult. The instructor needs to be prepared for the course mentally and pedagogically. The practitioner stated in the journal that:

I realized that I had never been in a situation where asking questions was so strategic. He should be very well-prepared because he gives tasks and specific problems from daily life. He should keep the students busy with activities.

In this setting, the instructor will need to be motivated to plan for the class. If the instructor is not prepared for the course and he/she does not know how to use the devices and tools in the class, the SCALE-UP system will not be effective. Moreover, class management skills of the instructor are also important because there are a lot of students in the class. The practitioner hesitates:

I think it is really difficult to motivate the instructors of SCALE-UP classes because it requires preliminary preparation for both the subjects and the digital devices. ... the management of these classes may be difficult for inexperienced teachers so I think a good, willing and dedicated SCALE-UP teacher may be prepared in a couple of years. Because there is no traditional lecturing, curriculum and syllabi should be extraordinary. Students should be motivated by making connections with current problems.

While there were no problems for students in the observed SCALE-UP classrooms, students may not be motivated in this system. In fact, their orientation towards traditional learning may hinder them from participating active learning environment. The practitioner doubts that:

SCALE-UP class may not fit to students' traditional learning habits. There is not any regular note-taking. So, they may have difficulties at the beginning and they may need motivation. 
The SCALE-UP systems require that instructors be well-prepared and that students adapt to a new form of instruction. This will be challenging to both the instructor and the students. In order to support instructors, they will need access to materials and people who are knowledgeable about this system. Students will need to gradually transition to this active learning environment. It will take time for both instructors and students to work effectively in this setting.

\section{Discussion}

In a SCALE-UP classroom, the room itself is one of the most important factors in supporting the success of the students (Kerlin, 2013). Many studies (Rogers, Keller, Crouse, \& Price, 2015; Foote, Neumeyer, Henderson, Dancy, \& Beichner, 2014a, 2014b; Gaffney et al., 2008; Oliver-Hoyo \& Beichner, 2004; Beichner \& Saul, 2003; Beichner, Saul, Allain, Deardorff, \& Abbott, 2000) report that these classes are technologically rich and designed to support large enrollments. Technological components are distinctive features of SCALE-UP and they provide many advantages. For instance, data collection about student learning can occur through clickers, which can save an instructor time by collecting data about a class as opposed to talking to each student. Instructors can also display materials and students can display their work on the screens by using a video projector (Oliver-Hoyo \& Beichner, 2004). This shares information between instructor and student, and student and student.

The tools used in SCALE-UP classrooms are different from traditional classes. The classrooms are comfortable and visually appealing. It is like a restaurant which has round tables with chairs. An instructor's station is equipped with technological tools and enables an instructor to easily manage every technological device in the class. Beichner (2006) defines technology as "a carefully considered means of accomplishing something", and Beichner and Saul (2003) emphasize that SCALE-UP classrooms were developed with considerable experimentation. The round tables make the communication between students easy. Nametags help grouping the students easily and identifying them even in large classrooms.

Contemporary approaches like active learning, collaborative learning, inquiry learning and activities such as problem-solving, hands-on activities and group work are implemented in SCALEUP classrooms. In the literature, some studies indicate student learning occurs as a result of these approaches (Benson, Moss, Ohland, Orr, \& Schiff, 2009; Oliver-Hoyo \& Beichner, 2004; Beichner \& Saul, 2003; Beichner et al., 2000). Benson et al. (2009), for instance, states a $22 \%$ normalized gain in student learning during SCALE-UP instruction. It has been suggested that students learn more physics in classes where they interact with faculty, collaborate with peers on interesting tasks, and are actively engaged with the material they are learning (Beichner et al., 2007). In another study, Dori and Belcher (2005) compared the success rates of more than 16,000 students over a five-year time span and found that the students in the SCALE-UP classrooms failed less than students in the traditional settings. Ultimately, the interactive and easy climate of the SCALE-UP classroom may affect the emotional orientation of students, such as attitude and motivation positively, and this may contribute the success.

SCALE-UP classrooms have many benefits in terms of learning. Critical thinking, communication, questioning, presentation, and teamwork abilities are supported in a SCALE-UP environment. In addition, students develop their cognitive skills and learn responsibility (Gaffney et al., 2008; Oliver-Hoyo \& Beichner, 2004; Beichner \& Saul, 2003; Beichner et al., 2000; Saul, Deardorff, Abbott, Allain, \& Beichner, 2000). Perkins (2005) remarks that the development of higher cognitive skills is a result of active and cooperative learning within group activities. Benson et al. (2009) state that the students in SCALE-UP are more motivated than the other ones. With the different abilities and skills that are developed, students develop more than they would in a traditional classroom.

An important part of the SCALE-UP classroom is the reduction of lecturing. According to Beichner et al. (2000) lecturing in a SCALE-UP classroom should be minimal, primarily for motivation and to provide an overview of topics. Benson et al. (2009) also reduced the classical lectures to about 15-20 minutes for instruction, generally including demonstration, simulation and Socratic dialogues in 
SCALE-UP classrooms. Oliver-Hoyo and Beichner (2004) focused on hands on activities as the driving force of the class time and interjected one or two short lectures of 15-20 minutes, between the activities in a two-hour session. According to Perkins (2005) in studio classess, lecturing should be short and rare; typically they might be like 15 minute mini-lectures. "Instead, students do many group projects, studying complex problems in depth. The content covered in the semester is less than in a more traditional class but the learning is greater".

When lecturing is reduced, different discussion and collaboration techniques can be used. Beichner et al. (2007) indicated that Socratic dialogues are useful in resolving cognitive conflicts of students, because he believes "the best learning is done while wrestling with ideas" (p. 6). Carefully designed tangibles and ponderables are used in the class (Gaffney et al., 2008; Beichner et al., 2006; Beichner \& Saul, 2003; Beichner et al., 2000) to help students to engage in the class lessons and to use their knowledge in the context of real-world situations (Gaffney et al., 2008). Students do not only study in the class, but they also do this in the out-of-class web assignments. These assignments are developed in order to reinforce and expand their learning. While they do the activities in collaboration with their peers and instructors in the class, web assignments enables students to work alone on the homework and come prepared to work in teams (Benson et al., 2008).

Along with its advantages for learning and teaching, SCALE-UP classrooms have some challenges for both teachers and students. DeBeck, Settelmeyer, Li, and Demaree (2010) and DeBeck and Demaree (2012) state that the efficacy of the SCALE-UP classroom is connected directly with the instruction. Only having the comfortable environment and the tools needed for SCALE-UP will not result in learning (Kerlin, 2013). Therefore, SCALE-UP classes may not always become successful and teachers may have difficulties in SCALE-UP classrooms if they are not experienced in this type of classroom. Luft (1999) emphasizes that making a change in instruction is a difficult process. Because SCALE-UP instruction needs an intensive preparation, enacting effective instruction in a SCALE-UP setting may take a few years for teachers who are not accustomed to it.

Beichner (2008) stated that students prefer SCALE-UP classes more than traditional ones. However, some students may have more difficulties due to their traditional learning habits. Students may not be motivated to learn in an active learning environment and they may need lecture notes. Moreover Gottfried et al. (2007) expressed that some students may even think helping other students is a waste of time. For this reason, students should be motivated at the beginning of the course and some reinforcements like group bonus points may be used (Oliver-Hoyo \& Beichner, 2004).

There may be some physical problems in SCALE-UP classrooms. Cassani (2008) stated that big SCALE-UP rooms may diminish teacher-student interaction, and for this reason smaller rooms may be preferred. Placing the instructor's station in the middle of the class or having more TAs may be a solution. Financial resources may be another challenge and this may be overcome with the collaboration of administrators and faculty to find this funding (Handelsman et al., 2004).

Money, effort and time have been used to cultivate innovative teaching methods (Neumeyer, Foote, Beichner, Dancy, \& Henderson, 2014). No method or technique is perfect, however SCALE-UP classrooms have promise. They improve student learning and they can be implemented a wide variety of disciplines (Foote et al., 2014b). Nonetheless, building and using SCALE-UP classrooms is a longterm process and not something that can be accomplished quickly (Rogers et al., 2015).

The universities in Turkey do not have SCALE-UP classrooms, however these classrooms may be beneficial for universities that have large-enrolled classrooms and for universities that do not have enough faculty. Successful implementation of a new system is not easy without the support of administration (Foote et al., 2014a), therefore, higher education administrators should be persuaded to put this system into practice in universities. 


\section{Conclusion}

As education continues to evolve, administrators, researchers and instructors are trying to discover new learning environments. Two of the main components of the contemporary context are active learning and technology enhancement in the classroom. A SCALE-UP classroom combines both; therefore it is strongly recommended that each university in Turkey has at least one SCALE-UP classroom.

In a SCALE-UP classroom, students seek the answers to thought provoking daily life questions in an intellectually challenging environment. This environment is a student-centered active learning environment that provides an alternative to traditional classes. The students are not bored because the instructor uses engaging instruction. In a class period, a learner can be involved in several methods such as cooperative learning with group discussions, problem solving, interactive learning activities, clicker questions, internet searches, hands-on activities, experiments, etc.

In recent years, Turkey has been embarking on some projects like the FATIH (The Movement to Enhance Opportunities and Improve Technology) project in order to integrate technology into education. The Council of Higher Education has also made use of technology; for instance, by establishing language learning laboratories at universities. SCALE-UP classrooms integrate technology into education, which has occurred in prior projects. Moving to a SCALE-UP approach should be simple, as there is some prior experience in using different innovations in higher education.

Implementing a new system in educational context is not an easy and quick process because of various obstacles. Financial problems may be one of them, however the budget of universities has been increased in recent years. Because administrators decide how to use the budget, they can be influential in the development of SCALE-UP classrooms. Once administrators are persuaded to use this system, SCALE-UP classrooms may be disseminated rapidly in Turkey. To help administrators know the value of SCALE-UP classrooms, here are six reasons that SCALE-UP classrooms are important to implement:

Reason 1. Learning responsibility shifts from the instructor to the students. A SCALE-UP classroom provides a student-centered active learning environment. It is an inquiry-guided teaching opportunity for the instructor and in this system students take on the responsibility of learning. This develops the self-directed learning skills of students and prepares them to life.

Reason 2. Cooperative learning ability develops among students. Classical lecturing is minimized in a SCALE-UP classroom. Students work in groups to learn the content from each other cooperatively, improving their teamwork ability.

Reason 3. Students strengthen their communication skills. A SCALE-UP classroom advances not only the students' teamwork ability but also their social skills, allowing much more time for teachergroup, teacher-student and student-student interactions. Periodically changing group members makes the learners more communicative class-wide. The use of big and small whiteboards develops the students' presentation skills. Signing the contract among the group members (and sometimes with the instructor) creates a sense of belonging to the learning community.

Reason 4. Technology incorporation serves to improve students' understanding. Interactive activities, e-homework, simulations and other useful resources increase student motivation. The instructor can promptly share the student's idea or solution on the individual screen and the whole class can see the solution.

Reason 5. Students remain engaged during the class period. SCALE-UP classrooms are not boring since the methods used in the lessons are changed continually. Based on the content, the instructor can use group discussion, hands on activities, demonstrations, simulations, experimentations, etc. Group discussions, competitions and clicker questions make the class engaging. 
Reason 6. Various assessment techniques can be used. The SCALE-UP classroom is conducive to different forms of assessment, which can guide the instructor of the class. By walking around the class, the instructor knows what concepts are difficult for students. When students share their class products, the instructor knows student knowledge is being constructed. And, clickers are useful to determine the prior and current knowledge of students. These are just a few assessment techniques, and there are many more.

No method is perfect, and SCALE-UP classrooms are far from perfect. However, SCALE-UP classrooms are an important first step towards creating student-centered technology incorporated learning environments in higher education. By building these classrooms, administrators are investing in the future of Turkey. They are providing students with the skills to be contributing members of the Turkish community. They are providing faculty with a way to improve the learning of future generations. The future of Turkey is important, and it is now the time to work towards the future.

\section{Acknowledgement}

A special thank to The Scientific and Technological Research Council of Turkey (TUBITAK) for funding Dr. Mustafa Erol under International Post-Doctoral Research Fellowship Program in 20142015. He is grateful to TUBITAK for the scholarship. 


\section{References}

Akınoğlu, O., \& Tandogan, R. Ö. (2007). The effects of problem-based active learning in science education on students' academic achievement, attitude and concept learning. Eurasia Journal of Mathematics, Science \& Technology Education, 3(1), 71-81

Aydede, M. N., \& Matyar, F. (2009). The effect of active learning approach in science teaching on cognitive level of student achievement. Journal of Turkish Science Education, 6(1), 115.

Bangert, A. W. (2004). The seven principles of good practice: A framework for evaluating on-line teaching. The Internet and Higher Education, 7(3), 217-232.

Barnes, K., Marateo, R. C., \& Ferris, S. P. (2007). Teaching and learning with the net generation. Innovate: Journal of Online Education, 3(4), 1-8.

Beichner, R. J. (2006). Instructional technology research and development in a US physics education group. European Journal of Engineering Education, 31(4), 383-393.

Beichner, R. J. (2008). The SCALE-UP Project: A student-centered active learning environment for undergraduate programs. Invited paper for the National Academy of Sciences. Retrieved from http://publish.illinois.edu/disruptivespaces/files/2014/07/SCALE-UP-Paper1.pdf.

Beichner, R. J., Dori, Y. J., \& Belcher, J. W. (2006). New physics teaching and assessment: Laboratoryand technology-enhanced active learning. In J. J. Mintzes, \& W. H. Leonard (Eds.), Handbook of College Science Teaching: Theory, Research and Practice (pp. 97-106). Washington DC: NSTA Press.

Beichner, R. J., \& Saul, J. M. (2003). Introduction to the SCALE-UP (student-centered activities for large enrollment undergraduate programs) project. In Proceedings of the International School of Physics, (July) (pp. 1-17). Retrieved from http://www.ncsu.edu/PER/Articles/Varenna_SCALEUP_Paper.pdf

Beichner, R. J., Saul, J. M., Abbott, D. S., Morse, J. J., Deardorff, D., Allain, R. J., ... Risley, J. (2007). The Student-Centered Activities for Large Enrollment Undergraduate Programs (SCALE-UP) Project. Research-Based Reform of University Physics, 1(1), 1-42. Retrieved from http://www.percentral.com/PER/per_reviews/media/volume1/SCALE-UP-2007.pdf

Beichner, R. J., Saul, J. M., Allain, R. J., Deardorff, D. L., \& Abbott, D. S. (2000). Introduction to SCALE UP: Student-Centered Activities for Large Enrollment University physics. In Proceedings of the 2000 annual meeting of the American Society for Engineering Education. Retrieved from http://files.eric.ed.gov/fulltext/ED459062.pdf

Benson, S. B. L., Moss, W., Ohland, M., Orr, M., \& Schiff, S. (2009, June). Adapting and Implementing the SCALE-UP Approach in Statics, Dynamics, and Multivariable Calculus. Paper presented at 2009 Annual Conference \& Exposition, Austin, Texas. Retrieved from https://peer.asee.org/5311

Benson, S. B. L., Moss, W., Schiff, S., Biggers, S., Orr, M., \& Ohland, M. (2008). Special sessionenhancing student learning using SCALE-UP format. In 2008 38th Annual Frontiers in Education Conference (pp. T2J-1-T2J-2). IEEE. doi:10.1109/FIE.2008.4720578.

Cassani, M. K. K. (2008). Impact of scale-up on science teaching self-efficacy of students in general education science courses (Doctoral dissertation). University of Central Florida, Orlando, Florida.

Chickering, A. W., \& Gamson, Z. F. (1987). Seven Principles for Good Practice in Undergraduate Education. AAHE Bulletin, 39, 3-7. doi:10.1016/0307-4412(89)90094-0

Chickering, A. W., \& Gamson, Z. F. (1991). Appendix A: Seven principles for good practice in undergraduate education. New Directions for Teaching and Learning, 1991(47), 63-69. doi:10.1002/tl.37219914708

Chickering, A. W., \& Gamson, Z. F. (1999). Development and adaptations of the seven principles for good practice in undergraduate education. New Directions for Teaching and Learning, 1999(80), 7581. 
Cochran-Smith, M., \& Donnell, K. (2006). Practitioner inquiry: Blurring the boundaries of research and practice. In J. L. Green, G. Camilli, \& P. B. Elmore (Eds.), Handbook of Complementary Methods in Education Research (pp. 503-518). Mahwah, New Jersey: Lawrence Erlbaum Associaties.

Crews, T. B., Wilkinson, K., \& Neill, J. K. (2015). Principles for good practice in undergraduate education: Effective online course design to assist students' success. Journal of Online Learning and Teaching, 11(1), 87.

Crouch, C. H., \& Mazur, E. (2001). Peer instruction: Ten years of experience and results. American Journal of Physics, 69(9), 970-977.

Cummings, K., Marx, J., Thornton, R., \& Kuhl, D. (1999). Evaluating innovation in studio physics. American Journal of Physics, 67(1), 38-44.

Çetinsaya, G. (2014). Yükseköğretimde Kalite İçin. Ankara: Ankara University Publications.

DeBeck, G., \& Demaree, D. (2012). Teaching assistant-student interactions in a modified SCALE-UP classroom. In 2011 Physics Education research Conference (Vol. 1413, pp. 167-170). AIP Publishing.

DeBeck, G., Settelmeyer, S., Li, S., \& Demaree, D. (2010). TA Beliefs in a SCALE-UP Style Classroom. In 2010 Physics Education Research Conference (Vol. 1289, pp. 121-124). AIP Publishing. doi:10.1063/1.3515176

Dori, Y. J., \& Belcher, J. (2005). How does technology-enabled active learning affect undergraduate students' understanding of electromagnetism concepts? The Journal of the Learning Sciences, 14(2), 243-279.

Erol, M., Isdari, B., Luft, J.A., Myers, D., \& Lemons, P.P. (2015). Creating active learning environments in undergraduate STEM courses. Athens, GA: University of Georgia Foundation. doi:10.13140/RG.2.1.2787.9121

Florman, J. C. (2014). TILE at Iowa: Adoption and Adaptation. New Directions for Teaching and Learning, 2014(137), 77-84.

Foote, K. T., Neumeyer, X., Henderson, C., Dancy, M., \& Beichner, R. J. (2014a). SCALE-UP Implementation and Intra-Institutional Dissemination: A Case Study of Two Institutions. In 2014 PERC Proceedings. doi:10.1119/perc.2014.pr.017.

Foote, K. T., Neumeyer, X., Henderson, C., Dancy, M. H., \& Beichner, R. J. (2014b). Diffusion of research-based instructional strategies: The case of SCALE-UP. International Journal of STEM Education, 1(1), 1-18.

Freeman, S., Eddy, S. L., McDonough, M., Smith, M. K., Okoroafor, N., Jordt, H., \& Wenderoth, M. P. (2014). Active learning increases student performance in science, engineering, and mathematics. Proceedings of the National Academy of Sciences, 111(23), 8410-8415.

Furtak, T. E., \& Ohno, T. R. (2001). Installing studio physics. The Physics Teacher, 39(9), 534-538.

Gaffney, J. D. H., Richards, E., Kustusch, M. B., Ding, L., \& Beichner, R. J. (2008). Scaling Up Education Reform. Journal of College Science Teaching, 37(5), 18-23.

Gottfried, A. C., Sweeder, R. D., Bartolin, J. M., Hessler, J. A., Reynolds, B. P., Stewart, ... Holl, M. M. B. (2007). Design and implementation of a studio-based general chemistry course. Journal of Chemical Education, 84(2), 265-270.

Günay, D., \& Günay, A. (2011). Quantitative developments in Turkish higher education since 1933. Journal of Higher Education and Science, 1(1), 1-22. doi:10.5961/jhes.2011.001

Handelsman, J., Ebert-May, D., Beichner, R., Bruns, P., Chang, A., DeHaan, R., ... Wood, W. B. (2004). Scientific teaching. Science, 304(5670), 521-522.

Hoellwarth, C., Moelter, M. J., \& Knight, R. D. (2005). A direct comparison of conceptual learning and problem solving ability in traditional and studio style classrooms. American Journal of Physics, 73(5), 459-462. 
Kalem, S., \& Fer, S. (2003). Aktif öğrenme modeliyle oluşturulan öğrenme ortamının öğrenme, öğretme ve iletişim sürecine etkisi. Kuram ve Uygulamada Eğitim Bilimleri, 3(2), 433-461.

Karamustafaoğlu, S., Coştu B., \& Ayas, A. (2006). Turkish chemistry teachers' views about an implementation of the active learning approaches in their lessons. Asia-Pacific Forum on Science Learning and Teaching, 7(1), 1-17.

Kerlin, S. D. (2013). Designing a SCALE-UP style instructional computer lab. In Proceedings of the Midwest Instruction and Computing Symposium. La Crosse, WI.

Kohl, P. B., \& Kuo, H. V. (2012). Chronicling a successful secondary implementation of Studio Physics. American Journal of Physics, 80(9), 832-839. doi:10.1119/1.4712305

Laws, P. W. (1991). Calculus-based physics without lectures. Physics Today, 44(12), 24-31.

Laws, P. W. (2004). A unit on oscillations, determinism and chaos for introductory physics students. American Journal of Physics, 72(4), 446-452. doi:10.1119/1.1649964

Leibold, N., \& Schwarz, L. M. (2015). The Art of Giving Online Feedback. The Journal of Effective Teaching, 15(1), 34-46.

Luft, J. (1999). Challenging myths. The Science Teacher, 66(4), 40-43.

Mandell, A. (2016). Cool passion: Challenging higher education by Arthur W. Chickering (review). The Review of Higher Education, 39(2), 301-305.

Mazur, E. (1997). Peer instruction: Getting students to think in class. In E.F. Redish, \& J. Rigden (Eds.), AIP Conference Proceedings 399 (pp. 981-988). American Institute of Physics: New York.

Mazur, E. (2009). Farewell, lecture. Science, 323(5910), 50-51.

McCabe, D. B., \& Meuter, M. L. (2011). A student view of technology in the classroom does it enhance the seven principles of good practice in undergraduate education? Journal of Marketing Education, 33(2), 149-159.

McLaughlin, J. E., Roth, M. T., Glatt, D. M., Gharkholonarehe, N., Davidson, C. A., Griffin, L. M., ... Mumper, R. J. (2014). The flipped classroom: A course redesign to foster learning and engagement in a health professions school. Academic Medicine, 89(2), 236-243.

Memnun, D. S. (2008). Sekizinci sınıfta permütasyon ve olasılık konularının aktif öğrenme ile öğretiminin uygulama düzeyi öğrenci başarısına etkisi. Uludă̆ Üniversitesi Eğitim Fakültesi Dergisi, 21(2), 403-426.

Merriam, S., B. (2013). Nitel araştırma desen ve uygulama için bir rehber (S. Turan, Trans. ). Ankara: Nobel Publications.

Miles, M. B., \& Huberman, A. M. (1994). Qualitative data analysis (2nd ed.). Thousand Oaks, CA: Sage.

Mintzes, J. J. (2006). Handbook of college science teaching. NSTA Press.

MOF - Ministry of Finance. (2006). General Directorate of Budget and Fiscal Control. Retrieved from http://www.bumko.gov.tr/TR,928/2006.html

MOF - Ministry of Finance. (2014). General Directorate of Budget and Fiscal Control. Retrieved from http://www.bumko.gov.tr/TR,4570/2014.html.

Neumeyer, X., Foote, K., Beichner, R. J., Dancy, M., \& Henderson, C. (2014). Examining the diffusion of research-based instructional strategies using social network analysis. In American Society for Engineering Education.

Oliver-Hoyo, M., \& Beichner, R. (2004). Scale-Up: Bringing Inquiry-Guided Learning to Large Enrollment Courses. In V. S. Lee (Ed.), Teaching and learning through inquiry: A Guidebook for institutions and instructors (pp. 51-69). Sterling, VA: Stylus.

Özoğlu, M., Gür, B. S., \& Gümüş, S. (2016). Rapid expansion of higher education in Turkey: The challenges of recently established public universities (2006-2013). Higher Education Policy 29(1), 2139. 
Panther Bishoff, J. (2010). Utilization of the Seven Principles for Good Practice in Undergraduate Education in General Chemistry by Community College Instructors. Retrieved from ERIC databases (ED521205).

Patton, M. Q. (2014). Nitel araştırma ve değerlendirme yöntemleri. (M. Bütün, \& S. B. Demir, Trans.). Ankara: Pegem.

Perkins, D. (2005). The case for a cooperative studio classroom: Teaching petrology in a different way. Journal of Geoscience Education, 53(1), 101-109.

Prince, M. (2004). Does active learning work? A review of the research. Journal of Engineering Education, 93(July), 223-231. doi:10.1002/j.2168-9830.2004.tb00809.x

Rogers, M., Keller, L. D., Crouse, A., \& Price, M. F. (2015). Implementing comprehensive reform of introductory physics at a primarily undergraduate institution: A longitudinal case study. Journal of College Science Teaching, 44(3), 82-91.

Saul, J. M., Deardorff, D. L., Abbott, D. S., Allain, R. J., \& Beichner, R. J. (2000). Evaluating introductory physics classes in light of the ABET criteria: An example from the SCALE-UP Project. In Proceedings of the 2000 Annual meeting of the American Society for Engineering Education.

SCALE-UP. (2015). Scale-Up Network. Retrieved from http://scaleup.ncsu.edu/

Singer, S. R., Nielsen, N. R., \& Schweingruber, H. A. (2012). Discipline based education research. Washington, DC: The National Academies Press.

Sokoloff, D. R., \& Thornton, R. K. (1997). Using interactive lecture demonstrations to create an active learning environment. The Physics Teacher, 35(6), 340-347.

Sorensen, C. M., Churukian, A. D., Maleki, S., \& Zollman, D. A. (2006). The new studio format for instruction of introductory physics. American Journal of Physics, 74(12), 1077-1082.

Taçman, M. (2007). Aktif öğrenme modeliyle oluşturulan sınıf ortamının öğrenciler üzerine etkisi. In The Proceedings of 7th International Educational Technology Conference, Near East University, North Cyprus.

Tirrell, T., \& Quick, D. (2012). Chickering's seven principles of good practice: Student attrition in community college online courses. Community College Journal of Research and Practice, 36(8), 580590.

Tuna, F. (2012a). Students' perspectives on active learning in geography: A case study of level of interest and usage in Turkey. European Journal of Educational Studies, 4(2), 163-175.

Tuna, F. (2012b). Current situation and analysis of geography teachers' active learning knowledge and usage in Turkey. Educational Research and Reviews, 7(18), 393-400.

Van Horne, S., Murniati, C., Gaffney, J. D., \& Jesse, M. (2012). Promoting active learning in technology-infused TILE classrooms at the University of Iowa. Journal of Learning Spaces, 1(2).

Yıldırım, A., \& Şimşek, H. (2011). Sosyal bilimlerde nitel araştırma yöntemleri. Ankara: Seçkin. 